\title{
ŻYCIE RELIGIJNE I SAKRAMENTALNE W INFIRMERII SZPITALA ŚWIĘTEGO DUCHA W RZYMIE W XVII-XVIII WIEKU ${ }^{1}$
}

\section{Streszczenie}

W rozwoju szpitalnictwa wielką rolę odegrał założony pod koniec XII wieku przez Guidona z Montperllier szpitalny zakon Świętego Ducha. Tenże zakon prowadził ufundowany w 1198 r. przez papieża Innocentego III największy w Europie Szpital Świętego Ducha w Rzymie, który stał się modelem dla innych szpitali w świecie chrześcijańskim. Do zjednoczenia Włoch pełnił on dwie funkcje: przytułku dla podrzutków (brefotrofium) oraz szpitala-lecznicy dla chorych (infirmeria). Obie te instytucje pod względem liczby podopiecznych (podrzutków i chorych) nie miały sobie równych na naszym kontynencie. W ostatniej ćwierci XVIII wieku mógł on pomieścić 2000 osób, w większości chorych.

W dawnych czasach szpitale pozostające pod zarządem kościelnym były miejscem, w którym szczególnie troszczono się o życie religijne podopiecznych. $Z$ jednakową troską dbano w nich o fizyczne wyleczenie chorego, jak i o zbawienie jego duszy. Tak też było w rzymskim Szpitalu Świętego Ducha.

Praktyczna troska o życie duchowe chorych i dopełnienie przez nich sakramentów świętych należała do dyżurujących spowiedników, a także do kapłanów polecających duszę umierających Bogu (raccommandatori dell'anime). W XVII wieku wszyscy oni byli zakonnikami Świętego Ducha. W późniejszych czasach, zwłaszcza w XVIII wieku, funkcję te często pełnili kapłani spoza szpitala, głównie kapucyni. Liczba wymienionych duchownych zmieniała się w zależności od potrzeb, zwiększała się na ogół latem wraz ze stałym w tym okresie wzrostem skali zachorowań i tym samym nasilenia umieralności w szpitalu.

* Marian Surdacki - prof. dr hab. nauk humanistycznych, Instytut Pedagogiki, Katolicki Uniwersytet Lubelski Jana Pawła II

e-mail: marian.surdacki@kul.pl

https://orcid.org/0000-0002-4649-8567

${ }^{1}$ Artykuł powstał w ramach projektu: nr 2018/29/B/HS3/02235 (Infirmeria Szpitala Świętego Ducha w Rzymie w XVIII wieku) finansowanego przez Narodowe Centrum Nauki. 
Głównym obowiązkiem spowiedników i polecających duszę Bogu było udzielanie sakramentu spowiedzi pensjonariuszom szpitalnym, zwłaszcza nowo przybyłym, a w sytuacji zagrożenia życia udzielenie im wiatyku i ostatniego namaszczenia na każde wezwanie dyżurnych, a także w wolnych chwilach pogłębianie podstaw wiary chrześcijańskiej chorych. Konsekwencją spowiedzi było zawsze udzielanie chorym komunii świętej. Ze wszech miar starano się zabezpieczyć, by żaden z chorych nie zmarł bez sakramentów świętych oraz by przy konających zawsze obecny był kapłan polecający duszę Bogu.

Słowa kluczowe: Szpital Świętego Ducha; życie religijne; sakramenty święte; spowiednicy; Rzym; chorzy

$* * * * *$

W rozwoju szpitalnictwa i działań opiekuńczo-dobroczynnych wielką rolę odegrał założony pod koniec XII wieku przez Guidona z Montperllier szpitalny Zakon Świętego Ducha, tzw. duchaków. Zwłaszcza w średniowieczu nie miał sobie równych na polu rozwijania dzieła miłosierdzia, które aż do Oświecenia stało się podstawą i inspiracją rozwoju wszelkiego rodzaju przedsięwzięć charytatywnych. Tenże zakon prowadził od 1204 r. ufundowany w 1198 r. przez papieża Innocentego III największy w Europie Szpital Świętego Ducha w Rzymie, który stał się modelem dla innych szpitali w świecie chrześcijańskim² ${ }^{2}$

Monumentalny w rozmiarach budowli Szpital Świętego Ducha był domem macierzystym duchaków oraz siedzibą generałów zakonu, którzy jednocześnie zawsze sprawowali funkcję przełożonych generalnych szpitala usytuowanego nad Tybrem. W źródłach przełożony ten zawsze występował pod określeniem commendatore, czyli komandor. Aż do zjednoczenia Włoch w 1870 r. szpital pozostawał pod protekcją papieża, w związku z czym nazywano go ,arcyszpitalem apostolskim" (archiospedale apostolico). Pomimo radykalnych zmian związanych ze sposobem administrowania zachował, jako infirmeria, swoją rangę aż do czasów obecnych, stanowiąc jedną z ważniejszych instytucji leczniczych dzisiejszego Rzymu ${ }^{3}$.

Od czasu dokonanej z polecenia papieża Sykstusa IV (1471-1484) rekonstrukcji szpital aż do zjednoczenia Włoch pełnił dwie funkcje: przytułku dla podrzutków (brefotrofium) ${ }^{4}$ oraz szpitala-lecznicy dla chorych (infirmeria). Obie te instytucje pod względem liczby podopiecznych (podrzutków i chorych) nie miały sobie równych na naszym kontynencie. W połowie XVIII wieku w szpitalu było hospitalizowanych jednocześnie 957 chorych, w ostatniej ćwierci XVIII wieku zaś szpital mógł pomieścić co najmniej 2000 osób, w większości chorych. Od 1870 r. wraz z przejęciem szpitala w administrację państwową i zaprzestaniem przyjmowaniu dzieci specjalizował się on wyłącznie w leczeniu chorych. O ile

${ }^{2}$ M. Surdacki, Dzieci porzucone w Szpitalu Świętego Ducha w Rzymie w XVIII wieku, Lublin 1998, s. 5.

${ }^{3}$ Tamże, s. 6

${ }^{4}$ Brephotropeum - dom podrzutków, sierociniec. Zob. A. Jougan, Stownik kościelny tacińsko-polski, Warszawa 1992, s. 78. Po włosku: brefotrofio. 
szpitale jako przytułki przechodziły wielowiekową ewolucję od funkcji socjalnej do funkcji medycznej, to Szpital Świętego Ducha w Rzymie od początku pełnił też funkcję medyczną. Szpital Świętego Ducha był lecznicą wielooddziałowąi wielofunkcyjną, przystosowaną do kuracji różnorodnych chorób, co było wówczas zjawiskiem wyjątkowym. Znajdowało się w nim sześć oddziałów: dla gorączkujących, rannych, chorych na gruźlicę, dotkniętych szkorbutem, chorych na kamienie oraz dotkniętych świerzbem.

Opiekuńcza funkcja Szpitala Świętego Ducha jako przytułku dla dzieci porzuconych (brefotrofio) była przedmiotem badań piszącego te słowa jeszcze w latach 80. XX wieku. Została gruntownie opracowana w formie dwu książek i serii artykułów w czasopismach i wydawnictwach polskich oraz zagranicznych, szczególnie włoskich ${ }^{6}$. Obecnie przedmiotem opracowania stała się, niezbadana dotąd, druga, infirmeryczna część tego szpitala. Doprowadzi to do powstania pierwszego całościowego studium instytucji ważnej dla ogólnoeuropejskiej kultury ${ }^{7}$. Prezentowany artykuł, o charakterze źródłowym stanowi fragment powstającego opracowania i przyczynek opisujący życie religijne pensjonariuszy Szpitala Swiętego Ducha w Rzymie, a w węższym sensie koncentruje się na życiu sakramentalnym i służbie kapłańskiej, odpowiedzialnej za administrowanie sakramentów świętych chorym szpitalnikom. Aby uniknąć dwuznaczności, należy zaznaczyć, że używany w tekście termin przełożony generalny szpitala (komandor) odnosi się do zarządzającego całym szpitalem, przełożony infirmerii zaś wyłącznie do sprawującego nadzór nad leczniczą częścią szpitala.

Podstawowe materiały źródłowe dotyczące Szpitala Świętego Ducha, liczące ponad 3000 teczek, przechowywane są w Archivio di Stato di Roma. Niespotykane bogactwo i różnorodność archiwaliów powodują konieczność ich trafnego doboru i selekcji, a nawet sondażu i kierowania się intuicją. Najbardziej intrygującym zadaniem badawczym będą kompleksowe analizy ogromnego zbioru hospitalizowanych, którzy podobnie jak rzesze podrzutków szpitalnych tworzyli łącznie swego rodzaju odrębny stan społeczny"

Zarówno w średniowieczu, jak i w okresie potrydenckim szpitale jako instytucje pozostające $\mathrm{z}$ reguły pod zarządem kościelnym były miejscem, w którym szczególnie troszczono się o życie religijne podopiecznych. Zgodnie z nauką Kościoła katolickiego z jednakową troską dbano o fizyczne wyleczenie chorego, jak i o zbawienie jego duszy. Tego typu filozofię ze szczególną gorliwością starano się

\footnotetext{
${ }^{5}$ Tamże, s. 77-82.
}

${ }^{6}$ Surdacki, Dzieci porzucone w Szpitalu; tenże, Il brefotrofio dell'Ospedale di Santo Spirito in Roma nel XVIII secolo, Conferenze 115, Varsavia-Roma 2002. Wykaz pozostałych prac autora na temat Szpitala Świętego Ducha zawiera artykuł cytowany w przypisie następnym (nr 6).

${ }^{7}$ M. Surdacki, Infirmeria Świętego Ducha w Rzymie w XVII-XVIII wieku. Perspektywy badaw$c z e$, „Archiwa Biblioteki i Muzea Kościelne”, 110 (2018) s. 381-394. Badania prowadzone są w ramach grantu NCN 2019-2022 „Infirmeria szpitala Świętego ducha w Rzymie w XVIII wieku”.

${ }^{8}$ Prawie wszystkie źródła wykorzystane dotyczące rzymskiego Szpitala Świętego Ducha przechowywane są w Archivio di Stato di Roma w dziale „Archivio dell'Archiospedale di S. Spirito" (dalej: ASR). Podawane numery sygnatur oznaczają poszczególne teczki, w których znajdują się cytowane dokumenty. 
stosować w szpitalach prowadzonych i zarządzanych przez zakony. Tak też było w rzymskim Szpitalu Swiętego Ducha, w którym życie religijne i duchowe jego pensjonariuszy było kształtowane przez rezydujących tam stale zakonników i zakonnice. Do rozwijania szczególnej gorliwości religijnej podopiecznych obligowały szpital jego bezpośrednie związki ze Stolicą Apostolską. Jako szpital papieski i największa placówka charytatywna w ówczesnym świecie chrześcijańskim stanowił on wzorzec dla pozostałych instytucji szpitalnych również $\mathrm{w}$ sferze kształtowania i organizacji życia religijnego.

Dnia 23 grudnia 1623 r. brat Domenico Borgarucci, sekretarz i archiwista Zakonu Świętego Ducha, formułując regulamin normujący sposób sprawowania rządów nad szpitalem przez duchaków, zaapelował, aby przybywających codziennie do szpitala chorych oraz podrzutki otaczać ze wszystkich sił na równi opieką duchową, jak i medyczną, a więc leczyć zarówno ich dusze, jak i ciała ${ }^{9}$. W trosce o duszę chorych, wydano w 1758 r. dekret informujący, że wszystkie wysiłki szpitala skierowane są na jeden tylko cel, ,aby poveri infermi byli z całą sztuką leczeni na ciele i na duszy"10. Spośród tych dwu trosk i posług, ważniejsza i bardziej pewna miała być ta druga, ponieważ zapewnia wieczne zbawienie duszy.

Praktyczna troska o życie duchowe chorych i dopełnienie przez nich sakramentów świętych należała głównie do dyżurujących na zmianę spowiedników, a także do tzw. kapłanów polecających duszę umierających Bogu (raccommandatori dell'anime). W 1679 r. kardynał Niccolò Acciaioli informował, że wszyscy oni zawsze byli zakonnikami Świętego Ducha. Tak wśród pierwszych, jak i drugich jeden musiał znać języki obce, w tym zaalpejskie, które umożliwiały przeprowadzenie spowiedzi i komunikację z cudzoziemcami ${ }^{11}$. W $1664 \mathrm{r}$. licencję do słuchania chorych w języku galijskim uzyskał francuski kapłan Joanni Goubaud, natomiast wizytujący szpital w 1696 r. kardynał Petrucci nakazał znaleźć spowiednika dla Niemców oraz Flandryjczyków ${ }^{12}$. W późniejszych czasach, zwłaszcza w XVIII wieku, funkcję tę, jak i polecających duszę, często pełnili kapłani innych parafii i klasztorów rzymskich, głównie kapucynów.

Liczba wymienionych duchownych zmieniała się w zależności od potrzeb, zwiększała się na ogół latem wraz ze stałym w tym okresie wzrostem zachorowań

${ }^{9}$ Surdacki, Dzieci porzucone w Szpitalu, s. 291-292; tenże, La vita religiosa nel „Conservatorio” dell'ospedale di Santo Spirito in Roma, nei secoli XVII-XVIII, „Ricerche di storia sociale e religiosa", 27 (1998) nr 54, s. 149-152..

${ }^{10}$ ASR, nr 61, Giornale. Memorie delle cose piu Notabili accadute circa gli Affari del ven. Archiospedale di S. Spirito da 28 Luglio 1758, sino a 28 Dicembre 1759, s. 31-32.

${ }^{11}$ ASR, nr 1409, Decreti di Visita dell'Eminentissimo Cardinal Acciaioli 15 Giugno 1679, $\mathrm{w}$ : Notificazione sopra varie disposizioni riguardanti il retto regime, governo, ed administratione dell'Apostolico Archiospedale di Santo Spirito, in Roma MDCCCXV, (dalej cyt. MSVD), s. 63-63; ASR, nr 1296, Atti della Visita Cardinal Acciauioli de'15 giugno 1679, w: Notificazione sopra diversi ogetti concernenti, l'osservanze regolare de'RR Canonici dell'Ordine di S. Spirito, NSVO, s. 29.

${ }^{12}$ ASR, nr 1049, Licenza di udire le confessioni In lingua francese 1664, w: NSVD , s. 56; ASR, $\mathrm{nr}$ 1409, Atti della Visita dell 'Eminentissimo Signor Cardinal Petrucci de 23 agosto 1696, w: NSVD, s. 81 . 
i tym samym nasilenia umieralności w szpitalu. Spowiedników w 1658 r. było dwóch, rekomendatorów zaś czterech ${ }^{13}$. W końcu lat 70 . XVII wieku latem było zawsze przynajmniej czterech spowiadających, lecz liczba ta ulegała zmianom. W razie potrzeby spowiednikom pomagali księża rekomendujący duszę, mający również prawo udzielania rozgrzeszenia ${ }^{14}$. Dwóch spowiedników w szpitalu odnotowano trakcie wizytacji z 1737 r. wobec sześciu kapłanów polecających dusze, w tym czterech zwyczajnych i dwóch dodatkowych - sopranumerari ${ }^{15}$. Sytuacja zmieniła się już w 1744 r., kiedy dwóch spowiedników i czterech rekomendatorów nie było w stanie podołać swym zadaniom. Ci ostatni przydzieleni po jednym na każdą z czterech gwardii dyżurujących w czterech oddzielnych oddziałach (quartieri) nie nadążali z pomocą sakramentalną umierającym. Gdy w tym samym czasie w danym oddziale kilku na raz chorych potrzebowało ostatniej posługi duchowej, nie miał im kto jej udzielić, w skutek czego niektórzy umierali bez asysty kapłanów. W tej sytuacji wyznaczono trzech innych duchowych, dwóch do pomocy polecającym dusze i jednego, który miał wspierać spowiedników i zakrystiana. Chcąc zaspokoić potrzeby religijne chorych, zarówno miejscowym kanonikom asystującym przy umierających (duchakom), jak i nowym kapłanom przyznano prawo słuchania spowiedzi, zwłaszcza w nocy. Zastrzeżono też, że w przypadku zwiększenia zachorowań na grypę, można będzie przyjąć jeszcze czterech kapucynów z zewnątrz, jak uczyniono to w poprzednim roku ${ }^{16}$. W $1747 \mathrm{r}$. w szpitalu przebywało aż czterech nadliczbowych księży polecających dusze, tymczasem liczba chorych wyraźnie się zmniejszyła, wobec czego mniej osób umierało. Skłoniło to przełożonego generalnego szpitala (commendatore) do zwolnienia dwóch z nich, wyznaczonych do dyżurów nocnych, tym bardziej że nie mając zajęcia, przesypiali w łóżku całą noc. Zapowiedział też, że mogą być przywróceni do służby na wypadek epidemii grypy, gdy zacznie umierać pięć, sześć osób dziennie ${ }^{17}$. Również w 1759 r. spowiedników szpitalnych było tylko dwóch, wobec ośmiu polecających duszę ${ }^{18}$.

Według regulaminu z 1654 r., normującego powinności osób duchownych i personelu świeckiego pracującego w Szpitalu Świętego Ducha, głównym obowiązkiem spowiedników było udzielanie sakramentu pojednania pensjonariu-

${ }^{13}$ ASR, nr 27, Ospedale di Santo Spirito. 1658. Rubricella delli Salariati di S. Spirito. 1658, $\mathrm{w}$ : Rubricella delli Salariati e ristretto di diverse tenute.

${ }^{14}$ ASR, nr 1409, Decreti di Visita ... Acciaioli 1679, s. 63-64; ASR, nr 3, Ordini da osservarsi nel'Hospidale dell'Archiospedale di S. Spiritro in Saxia per decreto dell'Signori Visitatori Apostolici, s. 88 .

${ }^{15}$ ASR, nr 902, Visita Apostolica deputata della Santità di N.S. Papa Clemente XII nel Sagro, et Apostolico Archiospedale, Casa, e Banco di S. Spirito in Sassia di Roma, principiata dall'... Signor Cardinal D. Leandro Porzia Visitatore Apostolico, il di 22 settembre 1737, s. 230. Wizytacja trwała do 1749 r. włącznie, choć jej tytuł wymienia tylko rok jej rozpoczęcia.

${ }^{16}$ ASR, nr 1301, Relazione fatta da Ferrini alla S.S. di tutto quello che si è fatto nello Spedale di S. Spirito, e del transporto dei Rognosi nello Spedale di S. Gallicano con utile.

${ }^{17}$ ASR, nr 902, Visita Apostolica deputata ...1737, s. 381.

${ }^{18}$ ASR, nr 3092, Istruzione per il Direttore delle Cose Spirituali del Venerabile Archiospedale, w: "Buste Misceanae", Assistenza agli infermi spirituali e corporale - Confessori e Raccomandatori dell'anima (brak daty). 
szom szpitalnym, zwłaszcza nowo przybyłym, a w sytuacji zagrożenia życia udzielenie im wiatyku i ostatniego namaszczenia na każde wezwanie dyżurnych. Do zadań „konfesorów” należało uczestniczenie w grzebaniu zmarłych na cmentarzu lub w kościele. Pod żadnym pozorem nie mogli opuszczać szpitala bez odpowiedniej zgody lub załatwienia zastępcy. W dniach swoich dyżurów zobowiązanibyliodprawiać msze święte iudzielać pensjonariuszom komuniiświętej, a przed obiadem i kolacją pobłogosławić posiłek i recytować przed ołtarzem szpitala Litanię do Wszystkich Świętych z modlitwą Świętego Sakramentu (l'orazione dl Santissimo Sacramento) za chorych; w soboty i święta maryjne, przed ołtarzem w małym szpitalu odmawiać Litanię do Matki Bożej, a w oktawę Zielonych Świąt śpiewać hymn do Ducha Świętego Veni Creator. Po jedzeniu i uprzątnięciu stołów, rankiem i wieczorem razem z kapłanami polecającymi duszę śpiewali Antyfonę do Matki Bożej i odmawiali przewidziane na dany czas modlitwy. Zmieniały się one w zależności od okresu liturgicznego roku. Mieli też uczestniczyć w solennych procesjach i mszach szpitalnych odprawianych w dniu śś. Kosmy i Damiana i w dzień Wszystkich Świętych. Wiele obowiązków duszpasterskich ciążyło na spowiednikach w okresie Wielkiego Postu. W Środę Popielcową dwóch z nich uczestniczyło $\mathrm{w}$ akcie posypywania chorym głowy popiołem, później święciło palmy, w Wielką Środę przeprowadzało spowiedź generalną dla wszystkich chorych. W każdą niedzielę święcili wodę i przynosili ją do wszystkich łóżek, kropiąc nią chorych i odmawiając przy tym Miserere, Antyfonę. W poświęconą wodę zaopatrywali w Wielką Sobotę wszystkie agendy, sale i pomieszczenia szpitalne. Razem we dwóch na zmianę zobowiązani byli odprawić 365 mszy świętych w ciągu roku, w tym połowę za dobroczyńców szpitala, pozostałe zaś za chorych i zmarłych pensjonariuszy ${ }^{19}$.

Nie mniej ważną rolę pełnili raccomandatori dell'anime. Ich posługa miała wymiar nie tylko religijny, ale też ludzko-psychologiczny dla pensjonariuszy będących u kresu życia. W związku z tym, że - jak częstokroć powtarzano - błogosławiona lub potępiona wieczność zależała od postawy umierającego i samego momentu śmierci, to na tych kapłanach spoczywała wielka odpowiedzialność za przyszłe losy i zbawienie odchodzących z doczesnego świata szpitalników. Dlatego zobowiązani byli z największą starannością i cierpliwością asystować znajdującym się w agonii, pocieszać słowem i uspokajać, wspomagać modlitwami, dawać wsparcie, pokrzepienie, tłumaczyć sens śmierci oraz czytać fragmenty tekstów z pobożnych ksiąg, Pisma Świętego, tekstów ojców Kościoła. Mieli również udzielać konającym sakramentu ostatniego namaszczenia olejami świętymi. Winni być w stałej gotowości, by wezwani przez obsługę mogli natychmiast przybyć do konającego i polecić dusze Bogu, jak nakazywał rytuał kościelny. Przed udaniem się na odpoczynek duchowny udzielał na noc będącym w agonii ostatniego namaszczenia. Gdy pacjent zakończył życie, asystujący przy śmierci wzywał kierownika dyżurnej gwardii, który w jego obecności rozbierał zmarłego i przygotowywał go do pochówku. Jeśli zmarły chowany był w kościele, zakonnik rekomendujący dusze towarzyszył spowiednikowi w obrzędzie pogrzebowym. Podobnie jak spowiedni-

${ }^{19}$ ASR, nr 1409, Regole da osservarsi nell'Arcispedale di San Spirito in Sassia 1654, s. 15-20. 
cy, duchowni ci zobowiązani byli odprawiać codziennie msze święte, na zmianę każdy w swoim tygodniu, tak by ich liczba wyniosła w sumie $365 \mathrm{w}$ ciągu roku, $\mathrm{z}$ tym że w niedziele msze św. celebrowali w oddziale szpitalnym dla szlachetnie urodzonych (Spedale dei Nobili). Ci, którzy nie sprawowali dyżuru w aktualnej gwardii, siadali do stołu w pierwszej turze, aby pobłogosławić posiłek i złożyć za niego dziękczynienie, umożliwiając tym samym płynną zmianę służby z tymi, co byli na niej wcześniej. Ponadto, razem ze spowiednikami, winni uświetniać obrzędy i uczestniczyć w nabożeństwach śpiewanych we wszystkie niedziele i inne święta obowiązkowe dni roboczych oraz Wielkiego Postu, Ponadto jeden z nich w Wielki Czwartek chodził do bazyliki św. Piotra asystować w poświęceniu Olejów Świętych, które miał dostarczyć do szpitala ${ }^{20}$.

Zgodnie z bardzo dawną zasadą i zwyczajem chory po przybyciu do szpitala i przejściu wstępnych badań lekarskich zobowiązany był wyspowiadać się u jednego $\mathrm{z}$ dyżurujących spowiedników, a następnego dnia rano przyjąć komunię świętą ${ }^{21}$. Można więc przypuszczać, że każdy, kto chciał znaleźć się szpitalu, musiał być osobą wierzącą 22 . Pierwszą spowiedź, obowiązującą każdego chorego, należało więc odbyć zaraz po zgłoszeniu się do szpitala, w czasie najbardziej wygodnym i sprzyjającym. Szczególnie ważna była ona dla ciężko chorych, którzy lada moment mogli odejść na sąd ostateczny ${ }^{23}$.

Według regulaminu z 1759 r. miał tego dopilnować dyżurny spowiednik, który chodząc rano i po obiedzie po szpitalu i kierując się listą chorych dopiero co przyjętych do szpitala sporządzoną przez kierownika dyżuru, umawiał ich do spowiedzi. Zdarzało się, że z powodu zbyt dużej liczby nowo przybyłych lub złego samopoczucia nie wszystkich dało się wyspowiadać jeszcze tego samego dnia. By usprawnić dalsze postępowanie, jeden z przełożonych kanoników odnotowywał osoby niewyspowiadane i czekające na dopełnienie tej powinności w następnych dniach u dyżurnych spowiedników lub jednego z zakonników przychodzących codziennie z zewnątrz do szpitala. Niektórych jednak nie można było rozgrzeszyć, toteż wydano regulamin, wedle którego spowiednicy nie mogli udzielać absolucji w sytuacjach wątpliwych, z powodu złej dyspozycji zdrowotnej lub innych przyczyn, zwłaszcza gdy penitenci nie byli w stanie zagrożenia życia. Gdy spowiednik nie mógł ich dopuścić do spowiedzi i rozgrzeszyć, niektórzy wymyślali różne preteksty, aby przystąpić do komunii świętej. Zarządzono więc, by zakrystian obchodzący wieczorem i rankiem sale szpitalne, pytał, czy chcą i czy mogą

${ }^{20}$ ASR, nr 1409, Regole da osservarsi nell'Arcispedale di San Spirito in Sassia 1654, s. 12-15; ASR, nr 1409, Regole da osservarsi nell'Arcispedale di San Spirito in Sassia. In Roma Per Michele Cortellini. 1654, w: MSVD, s. 21-25.

${ }^{21}$ ASR, nr 3092, Istruzione per il Direttore delle Cose Spirituali; Biblioteca Apostolica Vaticana, Barberino Latino 10683, cap. II. Relatione del modo, che si tiene da religiosi di Santo Spirito in Sassia di Roma nel governo dell'Archiospedale Apostolico di Santo Spirito, et dell'ordine, che si osserva nella cura degli infermi, et esposti, scritta da fra Domenico Borgarucci religioso, et secretario del medessimo Ordine, s. 2-29v.

${ }^{22}$ R. Gregoire, ,, Servizio dell'anima quanto del corpo” nell'ospedale romano di Santo Spirito, „Ricerche per la Storia Religiosa di Roma”, 3 (1979) s. 221-254.

${ }^{23}$ ASR, nr 61, Giornale. Memorie delle cose piu Notabili, s. 32. 
przyjąć komunię, pozostawiając im pełną swobodę decyzji, a następnie przekazał dyrektorowi informacje o niedopuszczonych do tego sakramentu. Ten, jako odpowiedzialny za życie religijne chorych, odnotowywał ich w tajnej księdze i powierzał opiece duchowej innym księżom, którzy przybywali na całodzienną służbę do szpitala. Uznano za niewskazane ponowne oddawanie tych osób w opiekę spowiedników, od których nie uzyskali wcześniej absolucji, ponieważ sądzono, że osoby te wymagają „bardziej kochającej i majestatycznej ręki potrzebnej do uzdrowienia". Po rozgrzeszeniu ,trudnych” penitentów księża powiadamiali dyrektora, który zapisawszy ten fakt w sekretnej księdze, polecał zakrystianowi udzielić im następnego dnia sakramentu Eucharystii lub wiatyku, jeśli byli w stanie zagrażającym życiü ${ }^{24}$.

Wynika z powyższego, że w szpitalu działały dwie grupy spowiedników. Pierwszą stanowili miejscowi spowiednicy dyżurni, członkowie Zakonu Świętego Ducha, spowiadający masowo nowo przybyłych pacjentów, często w pośpiechu z uwagi na zły stan zdrowia penitentów. Do drugiej grupy zaliczano spowiedników przybywających z zewnątrz, kapłanów świeckich lub zakonników z innych zgromadzeń, cierpliwych, wyrozumiałych, wnikliwych i pełnych żarliwego miłosierdzia i bardziej wyspecjalizowanych $\mathrm{w}$ udzielaniu tego sakramentu, którym powierzano przypadki szczególnie trudne, jakich nie byli w stanie rozwiązać dyżurujący spowiednicy. Gdy po dopełnieniu pierwszej spowiedzi pacjent przeżył i dłużej pozostawał w szpitalu, następną miał odbyć już u jednego z księży dochodzących, by mógł wyspowiadać się bardziej gruntownie i wnikliwie. Władzom szpitala bardzo zależało na regularnych wizytach tej drugiej grupy spowiedników, gdyż jak twierdzono, od ich misji zależał ostateczny los chorych pensjonariuszy ${ }^{25}$.

Wizytujący szpital w 1679 r. kardynał Acciaioli pisał, że chorych przybywających do tej placówki, w zależności od stanu zdrowotnego, spowiada się przed położeniem na łóżko bądź kładzie się ich najpierw na nie, by mogli przygotować się do sakramentu pokuty ${ }^{26}$. Wybór najbardziej odpowiedniego momentu i okoliczności do odbycia spowiedzi przez chorych dopiero co przybyłych do szpitala był sprawą kontrowersyjną. Toteż stanowisko władz szpitala w tej kwestii często się zmieniało, ponieważ nie można było wybrać uniwersalnego dla wszystkich chorych rozwiązania. Natychmiastowa spowiedź „,z drogi” (,z biegu”) stawała się powierzchowna, $\mathrm{z}$ kolei odwlekanie sakramentu pokuty i pojednania w wypadku ciężko chorych, w obliczu grożącej śmierci czy utraty świadomości, mogło skutkować jego nieodbyciem. W 1737 r. kardynał Leandro Porzia złagodził dawniejszą praktykę, która zabraniała kłaść na łóżkach nowo przyjęte osoby przed wcześniejszym wyspowiadaniem się, bowiem, jak twierdził, spowiedzi odbywane w pospiechu przez chorych, przygnębionych podróżą i słabością nie były skończone $^{27}$ i kompletne. Zarządził więc, by nowych chorych natychmiast położyć na łóżko, aby się pokrzepili i posilili, a następnie nakłonieni i pouczeni przez spowiedników dopiero wtedy przystąpili do wyznania grzechów. Panował też wcze-

\footnotetext{
${ }^{24}$ ASR, nr 3092, Istruzione per il Direttore delle Cose Spirituali.

${ }^{25}$ Tamże.

${ }^{26}$ ASR, nr 1409, Decreti di Visita ... Acciaioli 1679, s. 64.

${ }^{27}$ Wyraz wyróżniony w źródle.
} 
śniej zwyczaj, że chcąc jak najszybciej udzielić komunii ze względu na pobożność lub grożące niebezpieczeństwo, wzywano spowiednika, by jeszcze w dniu przyjęcia wieczorem wyspowiadał chorego, następnego dnia rano zaś udzielano mu komunii. Od tej pory niezależnie od spowiedzi odbytej poprzedniego dnia wieczorem i tak rano przed komunią winien chorego odwiedzić spowiednik ${ }^{28}$.

Postanowienie wizytacyjne z 1737 r. nie były całkowicie przestrzegane i wprowadzone w życie, wskutek czego panował w tym względzie duży nieporządek. W 1741 r. wizytator kardynał Severio Gentili z dezaprobatą informował, że nadal praktykowany jest zwyczaj spowiadania chorych natychmiast po przyjęciu do szpitala, przez co pozbawia się ich możliwości odpoczynku i dokonania świadomego rachunku sumienia. Dotyczyło to zwłaszcza chorych przybywających spoza Rzymu, którzy zmęczeni i „,oszołomieni” nie byli w stanie godnie i z refleksją dokonać prawdziwej spowiedzi. Chcąc temu zaradzić, wizytator powtórzył dyspozycje swego poprzednika i polecił spowiednikom, aby dawali penitentom konieczny czas na przygotowanie się do sakramentu pojednania i zrobienia prawdziwego rachunku sumienia. Dlatego należało ich najpierw położyć do łóżka, a dopiero potem przeprowadzić spowiedź, aby w obliczu zagrożenia życia i ciężkiej choroby mogli należycie pojednać się Bogiem. Wizytator stwierdził również, że rekomendujący duszę nie mieli uprawnień do spowiadania, co szkodziło przede wszystkim umierającym, gdyż właściwi spowiednicy w czasie nocy spali. Zarządził więc przeszkolenie tych zakonników w zakresie spowiedzi i nadanie im prawa słuchania i rozgrzeszania, tak by w każdym momencie byli gotowi posłużyć osobom, których stan zdrowotny gwałtownie się pogarszał. Zdaniem kardynała nie powinna się zdarzyć sytuacja, żeby w czasie nocy nie było przynajmniej jednego kapłana gotowego do wyspowiadania osób z zagrożeniem życia ${ }^{29}$. W anonimowym XVIII-wiecznym dokumencie zanotowano, że z uwagi na ignorancję „tylko Bóg jeden wie od jakiego czasu, niejeden ciężko chory, nie był spowiadany”. Wielu zaś innych penitentów z wysoką gorączką po przybyciu do szpitala zamiast być skierowanym najpierw na łóżko, nagle musiało odbywać spowiedź, często upadając w konfesjonale i tym samym pogłębiając chorobę. Dalej autor dokumentu pytał: „Jak to możliwe, że jeden ksiądz może pomóc tak wielkiej liczbie umierających?”. Niejako sam sobie odpowiedział, stwierdzając, że wskutek takiej sytuacji wielu z nich umiera bez pomocy duchownego ${ }^{30}$.

Kontrowersje dotyczące czasu odbywania spowiedzi i przyjmowania komunii świętej dotyczyły głównie nowoprzyjętych, ciężko chorych pacjentów, z dużym zagrożeniem życia, w wypadku których długie oczekiwanie na posługę duszpasterską było ryzykowne. Takim sytuacjom sprzyjały okresy epidemii. Do szpitala trafiały jednak i osoby z łagodniejszymi dolegliwościami czy chorobami chronicznymi, które mogły nieco zaczekać ze spełnieniem powinności religijnych, aby nie czynić zamieszczania i chaosu. Według relacji z $1759 \mathrm{r}$. w porze rannej nie było precyzyjnie ustalonej godziny spowiedzi i komunii świętej dla nowo przyby-

${ }^{28}$ ASR, nr 905, Ordini e Decreti della Santa Visita Apostolica. 1737, s. 3.

${ }^{29}$ ASR, nr 902, Visita Apostolica deputata...1737, s. 105-106, 109.

${ }^{30}$ ASR, nr. 3092, Disordini, che sono nel Venerabile Arcispedale di S. Spirito, w: "Buste Miscelanae”, Assistenza agli infermi spirituali e corporali - Confessori e Raccomandatori dell'anima. 
łych chorych. Czyniono to według uznania i wygody zakrystiana, o różnych porach $\mathrm{w}$ lecie i zimie, budząc czasami chorych w trakcie najgłębszego snu. W reakcji na taki nieporządek, przełożony generalny szpitala Giovanni Maria Castelli zarządził, aby sakrament spowiedzi i komunii świętej chorych miał miejsce o stałej godzinie, niezależnie od pory roku oraz że czynności te zakończyć się muszą pół godziny przed dzwonkiem na generalną pobudkę całej „rodziny szpitalnej”31.

Największe problemy z zapewnieniem opieki duchowej i ostatniej posługi sakramentalnej chorym pojawiały się w okresach epidemii, kiedy to wielu z nich kończyło życie, nie odbywszy spowiedzi z powodu zbyt małej liczby kapłanów uprawnionych do jej udzielania. Chcąc zaradzić takim sytuacjom, w obliczu epidemii grypy panującej w 1746 r. sprowadzono do szpitala czterech dodatkowych spowiedników kapucynów, którzy udzielali sakramentu pojednania umierającym. Po ustaniu zagrożenia odesłano ich do macierzystego konwentu kapucyńskiego z wynagrodzeniem dla całej wspólnoty zakonnej w postaci wina i chleba ${ }^{32}$.

Według edyktów papieskich zakonni spowiednicy zobowiązani byli dwa razy dziennie przybywać do chorych z posługą spowiedzi oraz nauką zasad wiary świętej. W praktyce na początku lat 40. XVIII wieku nie czynili tego, a jeśli przychodzili, to zaniedbywali swoje powinności. Kardynał wizytujący upomniał więc spowiedników, a następnie rozkazał zastępcy przełożonego infirmerii (sotto priore), żeby w wypadku powtarzania się podobnych zaniedbań odnotowywał wszystkie nieobecności w specjalnej książce, a pod koniec miesiąca poinformował o tym zwierzchnika spowiedników - wikariusza (vicario) ${ }^{33}$. Zakonnicy przybywający spowiadać i służyć w szpitalu mieli obowiązek wpisywać się do księgi strzeżonej przez przełożonego infirmerii (priore). Ten nie miał jednak prawa ich zwolnić, lecz w wypadku, gdy byli nieobecni, spóźniali się, wcześniej wychodzili bez pozwolenia lub zaniedbywali obowiązki, byli niedbali, mało zdolni i niezaangażowani w posługę, zobowiązany był poinformować o tym przełożonego generalnego, władnego decydować o ich losie ${ }^{34}$. Dbając o sumienność opieki duchowej nad chorymi, nieco później w trakcie wizytacji, zmieniono spowiedników i rekomendujących duszę na bardziej zdolnych, pojętnych i pilnych. Zobligowano jednocześnie przełożonego infirmerii do czujniejszej kontroli, robienia notatek o pracy tych zakonników oraz pilnowania, by stosowali się do zaleceń papieży, zgodnie $\mathrm{z}$ drukowaną instrukcją umieszczoną w szpitalu, normującą sposób przeprowadzania spowiedzi i posługi duchowej chorym ${ }^{35}$.

Bardzo często chorzy przybywający do szpitala pochodzili z plebejskich stanów, w związku z czym wykazywali ogromną niewiedzę w podstawach wiary katolickiej i katechizmu. W konsekwencji niezdolni byli i nie zasługiwali na roz-

${ }^{31}$ ASR, nr 61, Giornale di Memorie delle Cose piu Notabili accadute circa gli affari del Ven. Archiospedale di S. Spirito dai 28 luglio 1758 sino ai dicenbre 1759. Rodzina szpitalna - familia dell'ospedale - to cały personel szpitala: osoby duchowne, lekarze i pielęgniarze oraz służba pomocnicza opiekująca się chorymi.

${ }^{32}$ ASR, nr 902, Visita Apostolica deputata ...1737, s. 110-110.

${ }^{33}$ ASR, nr 902, Visita Apostolica deputata...1737, s. 116.

${ }^{34}$ ASR, nr 905, Ordini e Decreti della Santa Visita Apostolica. 1737, s. 8v.

${ }^{35}$ Tamże, s. 5. 
grzeszenie. Zarządzono więc, aby spowiednicy nie udzielali w takiej sytuacji rozgrzeszania, lecz zaznaczyli na łóżku chorych, że wymagają dokształcenia w podstawach wiary przez pobożnych ludzi. W szpitalu nie było nikogo, kto konkretnie mógłby taką edukację religijną prowadzić, dlatego dyrektor zwrócił się o wykonywanie tego zadania nie do spowiedników, lecz do innych kapłanów, którzy zwykle przychodzili do szpitala. Mógł również polecić zakrystianowi, by w wolnych chwilach, zwłaszcza w okresie, gdy w szpitalu była mniejsza liczba chorych, objaśniał chorym tajemnice wiary, znaczenie miłości Boga, potrzebę skruchy serca i powierzenia się jego miłosierdziu ${ }^{36}$. Taką ewangelizację prowadzono w szpitalu od dawien dawna. W 1679 r. kardynał Acciaioli, powołując się na dekrety wydane w czasie wizytacji przez papieży Urbana VIII (1623-1644) i Aleksandra VII (1655-1667), przypominał przełożonemu infirmerii i kapelanom (cappellani) o obowiązku nauczaniu chorych w każdą niedzielę doktryny chrześcijańskiej. Apelował też do wszystkich kapłanów Rzymu, zwłaszcza korzystających z jałmużny pałacu apostolskiego, aby przybywali do szpitala spowiadać chorych, ugruntowywać ich wiarę chrześcijańską, jak też towarzyszyć i pocieszać ich podczas obiadu i kolacji. Księża ci mieli pozostawać do dyspozycji władz szpitala i spełniać wszystkie niezbędne potrzeby ${ }^{37}$.

Przeprowadzenie spowiedzi dla nowo przybyłych chorych, warunkujące przyjęcie i dalszy pobyt w szpitalu, było ważnym zadaniem spowiedników, lecz nie wyczerpywało ich obowiązków. Część chorych przebywała w szpitalu przez dłuższy okres, co wiązało się z wielokrotnym ponawianiem spowiedzi. Była to dla kapłanów-spowiedników i pozostałych duchownych okazja do pogłębiania wiary i katechizowania hospitalizowanych. Kompleksową instrukcję normującą powinności spowiedników i innych zakonników (religiosi), pełniących posługę w czterech największych szpitalach Rzymu, wydał papież Innocenty XI (1676-1689), a odnowił ją Klemens XII (1730-1740). Według niej duchowni po przybyciu do szpitala winni odwiedzić po kolei chorych i z każdym z nich z miłosierdziem zamienić parę słów, po czym przystąpić do spowiadania nowoprzyjętych, resztę czasu zaś poświęcić na asystowanie przy umierających. Podczas codziennej wizyty mieli poznać stan zdrowotny chorego i stwierdzić: czy jest to początek choroby, czy stan się pogorszył, czy występuje zagrożenie życia, czy nie było niebezpieczeństwa śmierci, czy wszedł w fazę rekonwalescencji. Dopiero po diagnozie, w zależności od stanu fizycznego, można było podjąć dalsze kroki i przyjąć sposób postępowania $^{38}$.

Jeżeli choroba była początkująca, duchowny winien zapytać, czy pacjent się już wyspowiadał i przyjął komunię świętą, po czym w delikatny sposób wyjaśnić sens choroby i cierpienia w kontekście zbawienia, zaznaczając, że wyzdrowienie czy śmierć zależą od woli Bożej. W następnej kolejności kapłan zobowiązany był zapytać, czy duszy chorego nie dręczy jakiś ciężar i czy nie przeoczył czegoś w poprzednim wyznaniu win oraz czy chciałby dokonać zwykłej lub generalnej spo-

${ }^{36}$ ASR, nr 3092, Istruzione per il Direttore delle Cose Spirituali.

${ }^{37}$ ASR, nr 1409, Decreti di Visita Acciaioli 1679, s. 64-65.

${ }^{38} \mathrm{ASR}, \mathrm{nr}$ 1409, Istruzione formata gia d'ordine della S.M. di papa Innocenzo XI rinnovata dalla Santita di Nostro Signore Papa Clemente XII, w: NSVD, s. 86-90. 
wiedzi, czując, że niebawem wezwany zostanie na sąd ostateczny. Początkujących i niegroźnie chorych polecono dokształcić w doktrynie wiary według rytu rzymskiego i zachęcić, gdy wyzdrowieją, do dalszego pogłębiania podstaw religii chrześcijańskiej ${ }^{39}$.

Jeszcze większą delikatność i dyskrecję zalecano w stosunku do osób z pogarszającym się stanem zdrowia. Duchowni winni uświadamiać, że dalszy ich los spoczywa tylko w ręku Boga, pytać, czy coś jeszcze nie obciąża ich duszy i zapewniać pełną miłosierdzia asystencję $\mathrm{w}$ momencie odchodzenia $\mathrm{z}$ tego świata. A kiedy w niebezpieczeństwie śmierci przyjmować będą wiatyk, kapłani winni odmawiać z nimi akt pokory, zaufania i miłości. By godnie przyjęli sakrament namaszczenia, należało im zasugerować ponowną spowiedź, jeśli od ostatniej minął dłuższy czas lub zataili jakiś grzech. Jeśli chorzy byli bliscy śmierci, kapłani wysłani przez lekarza mieli zachęcić ich do aktu skruchy, sprawić, aby ponownie wyznali grzechy, a następnie dać rozgrzeszenie, odmówić akty wiary, nadziei i miłości. Na koniec powinni udzielić umierającym odpustu in articulo mortis, przyznanego przez papieża Pawła III (1534-1549) ${ }^{40}$.

Z kolei pacjenci, którym choroba mijała lub znajdowali się w okresie rekonwalescencji, zobowiązani byli wyrazić modlitewną wdzięczność Bogu za przywrócenie zdrowia na ciele, ale także na duszy, jak stwierdzali bowiem wymienieni papieże, słabość i choroby pochodzą z grzechu. Dlatego zadaniem duszpasterzy szpitalnych było nakłanianie wyzdrowiałych do skorygowania swego życia, wyzbywania się grzechu i okazji do jego popełniania; a także do odbywania częstych spowiedzi, przestrzegania przykazań Bożych i kościelnych, wybrania sobie dobrego spowiednika, który poprowadzi ich właściwą drogą do zdrowia. Ocaleni i wybawieni od choroby nie powinni zapominać, że należy prowadzić dobre życie chrześcijańskie i służyć Bogu, tak by osiągnąć „zdrowie wieczne”"41.

W życiu religijnym, szczególnie sakramentalnym, kulminacyjne znaczenie posiada komunia święta, która jest z reguły bezpośrednim następstwem aktu spowiedzi. W sposób szczególny troszczono się o przyjęcie sakramentu Eucharystii przez chorych w szpitalu, często była to bowiem ostatnia komunia w ich życiu. Chodziło o to, by każdy umierający w szpitalu pozostawał w momencie śmierci w stanie łaski uświęcającej. Wielką więc wagę przywiązywano do godnego i świadomego przygotowania się chorych do przyjęcia tego sakramentu, a wcześniej do gruntownej i szczerej spowiedzi.

W 1759 r. stwierdzono, że od dawna utrzymywany był zwyczaj zobowiązujący chorych do przystępowania do komunii świętej rano następnego dnia, po tym jak dzień wcześniej przybyli do szpitala. Dochodziło wielokrotnie do lekceważenia, a nawet profanowania sakramentu Eucharystii, co było skutkiem niewłaściwej, w pośpiechu przeprowadzonej spowiedzi nowo przybyłych pacjentów. Niektórzy zatwardziali $\mathrm{w}$ grzechu i przyzwyczajeni do zła, nie dokładnie wyspowiadani i nie godni otrzymania komunii świętej, zmuszani byli do jej przyjmowania. W rezultacie powodowało to lekceważenie Najświętszego Sakramentu,

\footnotetext{
${ }^{39} \mathrm{ASR}, \mathrm{nr} 1409$, Istruzione formata, s. 87-88.

${ }^{40}$ Tamże, s. 88-90.

${ }^{41}$ Tamże, s. 90.
} 
„ruinę” duchową chorych, ciężkie zakłopotanie i niepokój sumienia spowiedników. W celu naprawienia i skorygowania takich praktyk wizytator określił zasady właściwej spowiedzi. Według nich po przybyciu do szpitala chory winien nieco odpocząc i dopiero będąc w łóżku, po dokonaniu gorliwego rachunku sumienia, mógł przystąpić do wyznawania grzechów przed dyżurnym spowiednikiem. Po spowiedzi zobowiązany był poinformować księdza zakrystiana, który przybywszy do niego, winien zapytać, czy chce odłożyć komunię świętą na późniejszy termin, np. do następnego ranka, by bardziej się do niej przygotować. Decyzję chorego zakrystian odnotowywał $\mathrm{w}$ książeczce wyspowiadanych, a następnego ranka miał wzbudzić chorego i przygotować go do omunii świętej ${ }^{42}$. Według rozporządzenia kardynała Castelli przy udzielaniu porannej komunii świętej miało uczestniczyć 6 giovani della guardia ${ }^{43}$. Asystowanie spowiednikom dyżurnym przy udzielaniu komunii świętej było jednym z podstawowych obowiązków członków tej służby. Udzielaniem Eucharystii zajmował się też dyrektor oraz zastępca przełożonego infirmerii ${ }^{44}$.

Regularne i częste przystępowanie do sakramentów spowiedzi i komunii świętej należało do najważniejszych obowiązków religijnych pensjonariuszy szpitalnych, stanowiło też zasadniczy fundament rozwoju i umacniania ich wiary i duchowości. Częstotliwość wypełniania tych sakramentów była normowana przez regulaminy. Według rozporządzenia z 1759 r. chorzy mieli przystępować do komunii świętej raz na miesiąc, a przynajmniej ci, którzy przez ostatnie 15 dni nie przystępowali do tego sakramentu. Zapewne inni, jeśli chcieli, mogli to czynić częściej, a zwłaszcza pacjenci w zagrożeniu życia, którym udzielano komunii świętej na każde wezwanie służby szpitalnej ${ }^{45}$. Wcześniej, w 1741 r. wizytator odnotował, że chorzy otrzymywali sakrament Eucharystii tyko jeden raz w ciągu dnia, tj. rankiem nazajutrz po przybyciu do szpitala. Skutkowało to tym, że wielu, których nie odnotowano w rejestrach, przebywało więcej niż miesiąc w szpitalu, nie dostąpiwszy komunii świętej. Ponadto wcześniej komunikujący nie otrzymywali tego sakramentu po raz wtóry, chyba że sami się upomnieli, a kiedy dochodziło do pogorszenia stanu zdrowia, dopiero wtedy byli ponownie spowiadani i udzielano im wiatyku z komunią. Pragnąc uniknąć takich zaniedbań, nakazano księdzu zakrystianowi prowadzenie rejestru tych, co komunikowali i umieszczenie na stoliku stojącym na przedzie każdego łóżka daty ostatniej komunii, tak aby chory co miesiąc mógł przyjąć sakrament Eucharystii ${ }^{46}$.

Chcąc umożliwić chorym comiesięczną komunię świętą, na dzień przed jej udzielaniem (w sobotę) zapraszano do przeprowadzenia spowiedzi nadzwyczajnych spowiedników z zewnątrz, ponieważ na miejscu było tylko dwóch szpital-

${ }^{42}$ ASR, nr 61, Giornale. Memorie delle cose piu Notabili, s. 78-79.

43 ASR, nr 1409, nr 1305, Relazione delle Cose dell'Archiospedale di S. Spirito nell'anno 1759 del ...Cardinal Castelli Pro Commendatore, Castelli l'anno 1759, s. 229, w: Notificazione sopra varie providenze riguardanti il regolamento e buon'ordine del Conservatorio di S. Spirito. In Roma, s. $146-148$.

${ }^{44}$ ASR, nr 3092, Istruzione per il Direttore delle Cose Spirituali.

${ }^{45}$ Tamże.

${ }^{46}$ ASR, nr 902, Visita Apostolica deputata ...1737, s. 106-107. 
nych spowiedników. Wyznaczenie godziny udzielania comiesięcznej komunii świętej, określanej też niekiedy ,generalną”, pozostawiono w gestii przełożonego infirmerii po konsultacji z dyrektorem ${ }^{47}$.

„Komunia generalna” organizowana była jednak tylko kilka razy w roku i miała miejsce także w innych szpitalach. Odbywała się corocznie na Boże Narodzenie, Wielkanoc, Zielone Święta, Wniebowzięcie Najświętszej Maryi Panny i w Święto Zmarłych. Uczestniczyli w niej nie tylko chorzy, ale także cały personel i służba szpitalna. O zamiarze odbycia komunii generalnej informowano przede wszystkim chorych, by mogli się do niej dobrze i godnie przygotowaćc ${ }^{48}$.

Pośpiech i zaniedbania w udzielaniu sakramentów powodował ogólny bałagan i zagrożenie dla sfery duchowej chorych, którzy wątpliwie rozgrzeszani i nie przygotowani należycie do komunii świętej byli zapominani i „mało kto o nich myślał, by umożliwić im przyjęcie Eucharystii”. Dlatego wizytator 1759 r. zobowiązał zastępcę przełożonego infirmerii do prowadzenia specjalnej książeczki i wpisywania w niej dzień po dniu chorych, którzy nie przyjęli jeszcze komunii, oraz nazwiska spowiednika udzielającego im rozgrzeszenia. Ponadto ów przełożony miał wysłać do nich innego kapłana z pośród tych, którzy przychodzą spowiadać do szpitala, aby dopilnował i udzielił chorym komunii świętej. Jednocześnie zakrystian miał obowiązek adnotować w biuletynie osoby wyspowiadane, a następnie po przyjęciu na ich prośbę sakramentu Eucharystii, także zapisać, że dopełnili już tego obowiązku.

Jedną z przyczyn częstych zgonów chorych bez przystąpienia do należnych sakramentów było zbytnie oddalenie pomieszczeń szpitala, w których przebywali spowiednicy i zakrystianin od sal chorych. Chcąc nie dopuścić do takich przypadków, przydzielono tym kapłanom miejsce w lokalu szpitala dla osób szlachetnie urodzonych (dei Nobili), usytuowanego w pobliżu łóżek pensjonariuszy. Niektórzy chorzy umierali bez opieki kapłańskiej i ostatniego namaszczenia, ponieważ ich stan zdrowotny nie był właściwie rozpoznany przez dyżurujących (guardia). Dlatego kardynał Saverio Gentili nakazał w 1741 r. głównym lekarzom i ich asystentom, po rozpoznaniu ciężkich przypadków, natychmiast informować gwardię $\mathrm{w}$ celu zapewnienia należnych sakramentów i asystencji agonalnie chorym ${ }^{49}$.

Kiedy chory znajdował się w niebezpieczeństwie śmierci, ofiarowano mu Eucharystię jako pokarm i depozyt na drogę życia wiecznego. Zresztą sama nazwa wiatyk wywodzi się od łacińskiego słowa via, czyli droga. Dążono do tego, by chorzy przyjmowali wiatyk w stanie pełnej świadomości swojego położenia. W Szpitalu Świętego Ducha decyzję o udzieleniu wiatyku podejmowali lekarze podczas rannych wizytacji. Jeśli stan ciężko chorego nie był ekstremalnie zły, wiatyku udzielano następnego dnia w czasie zwyklej komunii świętej. Nieznany autor dokumentu z XVIII wieku pisał, że istniały w szpitalu zaniedbania, gdyż nie praktykuje się już wiatyku, co najwyżej czasami w podczas porannej komunii generalnej. W reakcji na ten stan rzeczy zarządzono udzielanie wiatyku w zależności od potrzeb, o każdej porze dnia i nocy, nie czekając na poranną komunię

\footnotetext{
${ }^{47} \mathrm{ASR}, \mathrm{nr} 3092$, Istruzione per il Direttore delle Cose Spirituali.

${ }^{48}$ ASR, nr 1409, Decreti di Visita ... Acciaioli 1679, s. 64.

${ }^{49}$ ASR, nr 902, Visita Apostolica deputata ...1737, s. 111-113.
} 
ogólną. Lekarze asystenci przy okazji wizyt mieli obserwować ciężko chorych, oceniać ryzyko rychłej śmierci czy utraty przytomności, a następnego dnia rano poinformować dyrektora, by natychmiast zarządził udzielenie wiatyku. A ponieważ stan chorych mógł się pogorszyć z godziny na godzinę, ich sytuację miał także monitować dyżurny personel ${ }^{50}$.

Udzielanie wiatyku, jeśli sprzyjały temu warunki, miał poprzedzić sakrament pokuty, odbywany już nieco wcześniej. Jeśli stan chorego, który już dwa razy poprzednio się spowiadał, pogorszył się, a od ostatniej spowiedzi minęło dużo czasu, należało kolejny raz wezwać spowiednika pochodzącego z poza szpitala. Gdy takiego aktualnie nie było, z konieczności można było skorzystać z usług spowiednika dyżurnego. Przy dawaniu wiatyku uczestniczył zakrystianin, który pobożnym i donośnym głosem recytował akt żalu, po czym dyżurny spowiednik bądź rekomendujący duszę przy łóżku leżącego dziękował Bogu za nawiedzenie chorego ${ }^{51}$.

Wiatyk, zwany także „ostatnią komunią świętą”, można było w rzeczywistości przyjmować wielokrotnie, nie tylko w ciągu całego życia, ale i podczas pobytu w szpitalu w poszczególnych dniach, dopóki istniało niebezpieczeństwo śmierci. Po wiatyku osoba chora zwykle jeszcze przyjmowała sakrament namaszczenia. Można wówczas było mówić o obrzędzie połączonym. Te wszystkie trzy sakramenty, tj. pokuta, Eucharystia jako wiatyk i namaszczenie chorych, miały być udzielane w rzymskim Szpitalu Świętego Ducha. W praktyce nie zawsze były razem sprawowane. Bardzo często wiatyku udzielano wcześniej i dopiero w sytuacji skrajnego pogorszenia się zdrowia następowało ostatnie namaszczenie.

W 1759 r. komandor szpitala Giuseppe Maria Castelli stwierdził, że sakrament ostatniego namaszczenia uważny ,jako niebiański środek leczniczy, uzdrawiający nie tylko dla duszy ale i dla ciała" osób zagrożonych utratą świadomości i śmiercią powinien być udzielany chorym według przyjętego rytuału z wielką sumiennością, pilnością i szacunkiem. Nie należało jednak dawać go za wcześnie. Polecił więc lekarzom i ich asystentom wskazywać podczas codziennych wizyt chorych, wymagających niezwłocznego udzielenia ostatniego namaszczenia. W jego opinii dotychczas wizyty takie odbywały się zbyt rzadko, dlatego zalecił dyżurującym asystentom medycznym i dyrektorowi, obchodzić odtąd każdego dnia rano i wieczorem sale szpitalne i zgłaszać wymagających przyjęcia tego sakramentu. W praktyce, jak zaznaczył, obowiązki te wypełniał dotąd personel usługujący ${ }^{52}$.

Według innego rozporządzenia asystenci medyczni po stwierdzeniu, że chory znajduje się w stanie zagrażającym życiu, nie powinni czekać, aż straci świadomość, lecz szybko powiadomić dyrektora, by natychmiast zarządził ostatnie namaszczenie. A że kompleksowe wizyty lekarskie przeprowadzano tylko rano, kondycja wielu pacjentów mogła ulec w międzyczasie drastycznemu pogorszeniu. Aby wychwycić takie przypadki i zadysponować szybkie namaszczenie chorego, dyrektor wraz z dyżurującym lekarzem asystentem musiał ich odwiedzać, najpierw parę godzin po porannej wizycie medycznej, później po obiedzie. Wizy-

\footnotetext{
${ }^{50}$ ASR, nr 3092, Istruzione per il Direttore delle Cose Spirituali

${ }^{51}$ Tamże.

${ }^{52}$ ASR, nr 61, Giornale, Memorie delle cose piu Notabili, s. 107.
} 
ty te służyły zbadaniu, czy nie ma nowych chorych z pogarszającym się stanem zdrowia i wymagających udzielenia wiatyku. Jeśli minęło siedem lub osiem dni od momentu otrzymania przez ciężko chorych wiatyku, należało ów sakrament powtórzyć, przed udzieleniem ostatniego namaszczenia. W celu usprawnienia procedur zobowiązano dyrektora do oznaczania w biuletynie dnia, w którym po raz pierwszy został udzielony wiatyk oraz daty, kiedy powtórzono ten sakrament ${ }^{53}$.

Szczegółowy ceremoniał dla księży spowiedników i polecających duszę Bogu, dotyczący udzielania ostatniej posługi, konkretnie procedury udzielania wiatyku i namaszczenia w obrzędzie połączonym oraz asystowania przy śmierci wydał komandor Castelli. Udzielanie komunii świętej w formie wiatyku poprzedzało podniesienie przez kapłana Najświętszego Sakramentu i odmówienie razem z umierającym budującej go modlitwy. Bezpośrednio po tym następowało podanie sakramentu Eucharystii. Po krótkiej przerwie kapłan dokonywał olejami świętymi aktu ostatniego namaszczenia. Był to sakrament, który należało przyjąć z intencją i pragnieniem, zanim faktycznie się go otrzyma, zdarzało się bowiem, że udzielano go umierającemu bez świadomości ${ }^{54}$. Nierzadko bywało jeszcze gorzej, kiedy kapłan przybywał z olejami, a chory „,wyzionął już ducha" ${ }^{55}$.

Rekomendujący duszę, udzielając ostatniego namaszczenia, miał najpierw zweryfikować tożsamość chorego, po czym - jeżeli był on świadomy, zachęcić do pojednania i wyznania grzechów. Następnie po wspólnym wyrecytowaniu aktu skruchy kapłan dokonywał rozgrzeszenia. Wtedy rekomendator duszy udawał się po oleje święte i przywdziawszy komżę oraz stułę, powracał do łóżka chorego z zapaloną świecą wraz z asystującym pomocnikiem (giovane). Złożywszy na stole naczynia z olejami świętymi, zachęcał chorego do uczestnictwa $\mathrm{w}$ odmawianiu aktu wiary, nadziei i miłości. Wszystkie te modlitwy kapłan recytował głosem jasnym, zrozumiałym, po czym z powagą i nabożeństwem namaszczał chorego i przekazywał mu Najświętszy Sakrament. Gdy wiadomo było od lekarza lub z zewnętrznych oznak, że chory zbliża się do przejścia do wieczności, pokropiony wodą święconą, otrzymywał do ucałowania krzyż, który pozostawał w jego rękach. Kapłan miał być do końca przy umierającym i czytać mu powoli Akt Oddania i inne modlitwy. Starano się pilnować, aby we wspomniane sakramenty zaopatrzyć chorego, gdy był jeszcze przytomny. Bywało, że chory pozbawiony był już świadomości. Wtedy kapłan powinien próbować wydobyć od niego jakiś znak świadczący, że pragnie spowiedzi, aby udzielić mu rozgrzeszenia, i niezależnie od wszystkiego recytować wymienione akty. Często zdarzało się, że nieprzytomny słyszał i orientował się co się wokół niego dzieje, choć nie wyrażał na zewnątrz żadnego gestu ${ }^{56}$.

${ }^{53} \mathrm{ASR}, \mathrm{nr} 3092$, Istruzione per il Direttore delle Cose Spirituali

${ }^{54}$ ASR, nr 3092, Notificazione sopra di metodo di tenersi da sacerdoti confessori, e raccomendatori d'Anime per insinuarsico'moribondi dell'Apostolico Archiospedale di S. Spirito in Sassia. In Roma XDCCCXV, w: "Buste Miscelanae", Assistenza agli infermi spirituali e corporali - Confessori e Raccomandatori dell'anima, s. 9-28.

${ }^{55}$ ASR, nr. 3092, Disordini, che sono...

${ }^{56} \mathrm{ASR}, \mathrm{nr}$ 152, Metodo da tenersi dai Reverendi Sacerdoti Confessori, e raccomandatori di Anime nell'Archiospedale di S. Spirito di Roma nell'amministrare agli Infermi il Santo sagramento 
Po udzieleniu ostatniego namaszczenia przez spowiedników lub rekomendujących dusze, dalsza opieka, już tyko duchowa, nad umierającymi spoczywała w ręku tych drugich duchownych. W 1759 r. komandor Castelli zobowiązał kapłanów rekomendujących dusze Bogu do nieustannego odwiedzania osób w agonalnym stanie i pilnowania, by w ostatnich chwilach życia nie byli pozbawieni miłosierdzia $\mathrm{i}$ wsparcia $\mathrm{z}$ ich strony. W celu ułatwienia zadania tym kapłanom wydrukowano zbiór teologicznych aktów cnoty i pobożnych aktów strzelistych, wymawianych przy konającym. Kapłan, widząc pogarszający się stan ciężko chorego, nachyliwszy się nad jego łóżkiem, miał recytować ze szczególnym nabożeństwem modlitwy polecające Bogu duszę umierającego ${ }^{57}$. A ponieważ wielu chorych nie potrafiła samodzielnie odmawiać modlitw, bądź ze względu na nieznajomość tekstów, bądź ze uwagi na ciężki stan, kapłan miał je odmawiać nie w sposób ciągły, ale wolno, z przerwami, zachęcając przy tym chorego do wtórowania. Mógł dobierać modlitwy błagalne i akty strzeliste, kierując się swą roztropnością, gorliwością, w zależności od różnych okoliczności i szczególnych przypadków ${ }^{58}$.

Proces umierania wielu chorych trwał przez dłuższy czas, a u niektórych stan zdrowia się polepszał, dlatego zdarzało się, że polecający duszę, nie znając momentu śmierci, oddalali się od umierających, przez co byli nieobecni w chwili, gdy pacjenci kończyli życie. Zobowiązano więc dyrektora, aby informował przełożonego generalnego szpitala o tych polecających duszę, którzy niedbale wypełniali swoje powinności, pozbawieni byli miłosierdzia i gorliwości, uniemożliwiającej prawdziwe oddanie się umierającym, gdyż jak zaznaczono, „nie można dać tego innym, czego samemu się nie posiada". Dalsze decyzje w takiej sytuacji podejmował komandor, który miał zabezpieczyć „Winnicę Pańską w najlepszych robotników, którzy chcą i potrafią wykonywać sztukę, do której są powołani”. Jednocześnie pozostawiono dyrektorowi wolność we wszelkich innych decyzjach, które prowadziłyby do zbawienia duszy chorych. Dlatego miał on osobiście nadzorować wszystkich duchownych, szczególnie rekomendujących dusze ${ }^{59}$.

Pomimo ustawicznych nakazów naprawy sytuacja w opiece duchowej nad osobami w agonii nie poprawiła się, co z żalem podkreślał w $1781 \mathrm{r}$. kolejny przełożony generalny Domenico Sampieri. Twierdził, że kapłani polecający dusze zaniedbują swoje obowiązki w świadczeniu sakramentu namaszczenia i opieki nad umierającymi, lekceważąc kompleksowe wytyczne, jakie sformułował przed kilkunastu laty komandor Castelli, przy czym gorąco prosił o ich stosowanie. Zalecił zwłaszcza dyżury przy łóżkach ciężko chorych, póki są jeszcze w stanie świadomości i mogą skorzystać z duchowej pomocy. Mieli też często pytać, czy mają jeszcze potrzebę wyspowiadania się u nich, o ile byli spowiednikami. Jeśli nimi nie byli, musieli wezwać duchownych mających uprawnienia do jej przeprowadzania. Jak wspomniano, przy namaszczeniu chory kropiony był wodą święconą i całował krzyż, który wręczano mu do ręki lub kładziono w łóżku, a na końcu

dell'Estrema Unzione. (b. roku); ASR, nr 3092, Notificazione sopra di metodo, s. 9-28.

${ }^{57}$ ASR, nr 61, Giornale.Memorie delle cose piu Notabili, s. 108.

${ }^{58}$ ASR, nr 3092, Notificazione sopra di metodo, s. 9-28.

${ }^{59} \mathrm{ASR}, \mathrm{nr} 3092$, Istruzione per il Direttore delle Cose Spirituali. 
otrzymywał błogosławieństwo in articulo mortis według formuły z konstytucji Benedykta IV (1740-1758) zaczynającej się od słów Pia Mater Ecclesia ${ }^{60}$. Na jej mocy papież ten we wrześniu 1744 r. przyznał miejscowym, jak i obcym kapłanom przybywającym do szpitala z sakramentami świętymi pełnomocnictwa do udzielania wszystkim umierającym błogosławieństwa w obliczu śmierci ${ }^{61}$. Wskazane było udzielenie go, gdy chory miał jeszcze świadomość. Nie mniej ważne było pokropienie wodą święconą, która była zbawiennym środkiem zmuszającym „piekielnego wroga do ucieczki”62.

Komandor Sampieri zadbał też o większą liczbę nieodzownych sprzętów i pomocy liturgicznych, aby każdy polecający duszę rozpoczynający dyżur otrzymał od swego poprzednika książeczkę z rytuałem modlitw, naczynie na wodę święconą i dwa krzyże, gdyby te pozostawały jeszcze w rękach lub w łóżku umierających. Za wszelkie zaniedbania w polecaniu dusz chorych będących u kresu życia, tj. w udzielaniu im błogosławieństwa in articulo mortis, oraz za brak przy asystowaniu wymienionych rekwizytów, groziły duchownym surowe kary, włącznie ze zwolnieniem. Wiele wątpliwości budziła w owym czasie współpraca między rekomendatorami dusz a kierownikami dyżurującej służby. Winni temu byli przede wszystkim duchowni, którzy nie stosowali się do wcześniejszych dekretów, dlatego kontrolę nad nimi powierzył komandor szpitala kierownikom personelu pomocniczego, nie ujmując niczego z prerogatyw dyrektora do spraw duchowych w stosunku do polecających duszę. Cały zaś nadzór miał dzierżyć canonico prio$r e$, łącznie $\mathrm{z}$ wymierzanych kar dla niesumiennych kapłanów ${ }^{63}$.

Postawa kapłanów, zwłaszcza asystujących przy śmierci, ale także spowiedników budziła permanentnie wiele zastrzeżeń. Z rękopisu pochodzącego z $1800 \mathrm{r}$. wynika, że zanim funkcję komandora objął Ippolito Antonio Vincenti Mareri, w szpitalu służyli księża świeccy (diecezjalni), pełniąc funkcję spowiedników i polecających dusze. W czasie jego rządów w ich miejsce zaangażowano kapucynów, którzy mieli m.in. sporządzać testamenty. Lekceważyli jednak swoje obowiązki, byli samowolni i skorumpowani, ciągle grozili, że odejdą. Do tego dochodziły inne nieprawidłowości, przede wszystkim zaniedbywali posługę względem chorych, ponadto widywani byli z kobietami, podejrzewano ich o kradzież rzeczy należących do chorych. Niektórzy włóczyli się po szynkach i knajpach publicznych, skupywali na handel chleb od tragarzy szpitalnych, chodzili do kobiet, czasami sprowadzając je do swoich pokoi. Nade wszystko wykazywali arogancjęi i nie-

${ }^{60}$ ASR, nr 1409, Decreto per li sacerdoti dell'Archiospedale. D. Sampieri Commendatore 1781, w: DSVD, s. 288-290.

${ }^{61}$ ASR, nr 1409, Facoltà di dare la Benedizione in „Articulo Mortis” agl'Infermi. 1744, w: Notificazione sopra varie disposizioni riguardanti il retto regime, governo, ed administratione dell'Apostolico Archiospedale di Santo Spirito, in Roma MDCCCXV, (dalej cyt. MSVD), s. 120-121; ASR; nr 1301, Relazione fatta da Ferrini alla S.S. di tutto quello che si è fatto nello Spedale di S. Spirito, e del transporto dei Rognosi nello Spedale di S. Gallicano con utile.

${ }^{62}$ ASR, nr 1409, Decreto per li sacerdoti..., s. 290.

${ }^{63}$ ASR, nr 1409, Decreto per li sacerdoti..., s. 290-292. 
posłuszeństwo względem zarządzeń przełożonych szpitala. W końcu na mocy dekretu wizytacji apostolskiej z 1800-1801 r. zostali zwolnieni ${ }^{64}$.

Niekiedy zaniedbania w stosunku do konających wynikały z przyczyn obiektywnych. W $1741 \mathrm{r}$. wizytator ubolewał, iż ciężko chorzy nie mają dobrej opieki ze strony duchownych i często umierają w samotności, pozbawieni czuwania ze strony kapłanów. Wynikało to jednak ze zbyt małej ich liczby i rozproszenia po różnych kwaterach szpitalnych. Chcąc zapobiec takim sytuacjom, oprócz czterech zwyczajnych kapłanów polecających dusze, wzięto do pomocy dwóch innych, a kiedy nadal było ich za mało, dobrano jeszcze następnych dwóch tak, żeby chorzy kończący życie mieli opiekę przez całą dobę $e^{65}$. Nie poprawiono jednak sytuacji lokalowej osób zaangażowanych w posługę umierających, gdyż w 1759 r. pokoje dyżurnych pomocników nadal były zbytnio oddalone od kwater księży rekomendujących dusze. Powodowało to niewygodę i stratę czasu dla kapłanów, którzy zmuszani byli przemieszczać się, by zbudzić pomocników, towarzyszących im w posłudze osobom w ostatnich chwilach ich życia. Tym razem na interwencję komandora Castelliego zmodyfikowano układ kwater, przybliżając izby sypialne służby pomocniczej do pomieszczeń rekomendatorów. Ponadto wybito otwór między pokojem jednego z duchownych polecających dusze, a sypialniami pomocników. Umożliwiło to sprawowanie kontroli nad świecką służbą i zachowanie umiaru oraz powściągliwości w jej zachowaniu i słownictwie. Zarządzono też, by w sypialniach zawsze w nocy paliła się lampa ${ }^{66}$.

Choć Kościół starał się udzielać sakramentów świętych i rozgrzeszenia pensjonariuszom kończącym życie w szpitalu, to zdarzały się przypadki, że nie udało się lub nie zdążyło tych powinności dokonać. W tej sytuacji Innocenty XII (16911700) zgodził się w 1694 r. na udzielanie odpustu zupełnego wszystkim umierającym chorym. Warunkiem uzyskania odpustu była wcześniejsza spowiedź i komunia święta, a dla osób, które nie były w stanie tego uczynić, wystarczyło wyrazić mimiką twarzy skruchę i dać znak ustami lub westchnąć w sercu do Jezusa i wzywać pomocy Boskiej ${ }^{67}$. Papieże, jako protektorzy Szpitala Świętego Ducha przejawiali nieustannie troskę o zbawienie wieczne przebywających tam chorych pensjonariuszy. Klemens XII (1730-1740) swoim brewe z 1738 r. nadał władzę wszystkim spowiednikom świeckim i zakonnym udzielania rozgrzeszenia chorych z win i grzechów zastrzeżonych dla wyższych instancji kościelnych. W drugim zaś brewe $\mathrm{z}$ tego samego roku przyznał prawo księżom celebrującym msze święte przy jednym z trzech ołtarzy w szpitalu uwalniania dusz pensjonariuszy od

${ }^{64}$ ASR, nr, 3092, Memorie sopra la dimissione de Padri Capuccini del servigio dell'Archiospedale, w: "Buste Misceanae", Assistenza agli infermi spirituali e corporali-Confessori e Raccomandatori dell'anima. (b. d. m. w.)

${ }^{65}$ ASR, nr 902, Visita Apostolica deputata 1737, s. 108.

${ }^{66} \mathrm{ASR}, \mathrm{nr}$ 1409, Regolamento de quartieri per li raccomandatori delle anime. Giseppe Maria Castelli 1659, w: NSVD, s. 215-216.

${ }^{67}$ ASR, nr 7, Ristretto del contenuto di diversi chirografii, e decreti, che si conservano nell'Archivio di San Spirito, Memorie d'alcune bolle, brevi, rescritti, prerogative concernenti d'Archiospedale di S. Spirito ed Annessi 1748, w: Iura e documenta, s. 204v. 
cierpień czyśćcowych ${ }^{68}$. Dokładnie dwadzieścia lat później spowiednicy szpitalni otrzymali prawo udzielania rozgrzeszenia wszystkim, którzy nie spełnili przykazań wielkanocnych (precetto pasquale) ${ }^{69}$.

Ja już wspomniano, za organizacje i całokształt życia religijnego pensjonariuszy oraz nadzór nad wszystkimi kapłanami świeckimi oraz zakonnikami, sprawującymi posługę duszpasterską dla chorych odpowiedzialny był dyrektor do spraw duchowych $\mathrm{w}$ szpitalnej infirmerii. W instrukcji wydanej najprawdopodobniej 1759 r., normującej jego powinności, określany był jako canonico direttore, co znaczy, że był to jeden z duchaków - kanonik Zakonu Świętego Ducha, bo taką nazwę od dłuższego czasu nosili członkowie tej wspólnoty zakonnej. Pełnił on funkcję proboszcza wszystkich chorych zgromadzonych w szpitalu, „,wysłanych” przez własnych proboszczów, ze względu na chorobę, do rzymskiej placówki duchaków. Od momentu przekroczenia murów szpitalnych to jego trosce powierzeni zostali chorzy, którym miał zagwarantować opiekę duchową do ich śmierci lub wyzdrowienia. Sprawował on najwyższy nadzór nad zakrystianem, dwoma spowiednikami i ośmioma rekomendatorami duszy, a odpowiedzialny był tylko przed przewożonym generalnym szpitala i zarazem całego zakonu ${ }^{70}$.

Jego szczegółowe obowiązki polegały na codziennym przebywaniu w szpitalu, obchodzenie sal hospitalizowanych i sprawdzanie, czy jego wcześniejsze dyspozycje zostały wykonane przez podległych mu księży. Miał podczas tych wizyt obserwować chorych z pogarszającym się stanem zdrowia, pilnować, by zapewniono im przyjęcie sakramentów, w tym ostatniego namaszczenia i strzec, by kapłani polecający dusze odmawiali z nimi w ostatnich chwilach życia należne modlitwy. Przed udaniem się na spoczynek jeszcze raz musiał obejść sale chorych, zważając szczególnie na pacjentów w ciężkim stanie. Jeśli takich spotkał, miał wezwać księży polecających dusze, by towarzyszyli im w ostatnich chwilach życia. Aby uniknąć zaniedbań ze strony podległych mu księży i oszczędzić im uciążliwych nocnych obowiązków, mógł też w czasie swej ostatniej wieczorowej wizyty sam odprawić krótką miłosierną modlitwę-egzortę nad chorymi w ciężkim stanie, póki jeszcze mogli odmówić żarliwie akt żalu i krótko akt wiary, nadziei i miłości ${ }^{71}$.

W sumie obowiązkiem dyrektora duchownego dyrektora było odbycie aż czterech wizytacji w ciągu dnia, w różnych porach, we wszystkich oddziałach szpitalnych, w których leżeli chorzy. Pierwsza, ranna służyła uporządkowaniu kwestii związanych z udzielaniem komunii świętej osobom świeżo przybyłym do szpitala. Druga odbywała się tuż po wizycie lekarskiej lub zaraz po obiedzie. W jej trakcie odnotowywano chorych z pogarszającym się stanem zdrowia, z intencją szybkiego ich wyspowiadania. Trzeciego obchodu dokonywał dyrektor wraz z dyżurnym lekarzem asystentem kilka godzin po dwóch pierwszych wizytach, w celu

${ }^{68} \mathrm{ASR}, \mathrm{nr} 7$, Ristretto del contenuto di diersi chirografii..., s. 208v-209.

${ }^{69} \mathrm{ASR}, \mathrm{nr} 61$, Giornale, Memorie delle cose più Notabili accadute circa gli Affari del ven. Archiospedale di S. Spirito da 28 Luglio 1758, sino a 28 Dicembre 1759.

${ }^{70} \mathrm{ASR}, \mathrm{nr} 3092$, Istruzione per il Direttore delle Cose Spirituali. Z tego dokumentu wynika, że liczba spowiedników i rekomendatorów zmieniała się.

${ }^{71}$ Tamże. 
stwierdzenia, czy od ostatnich wizyt nie zdarzyła się sytuacja wymagająca natychmiastowego udzielenia wiatyku lub namaszczenia. Ostatnia, czwarta wizytacja odbywała się na początku nocy i miała na celu odnotowanie nowo przybyłych w międzyczasie chorych i zapytanie ich, czy są wyspowiadani. Przed samym zaś odejściem z dyżuru dyrektor jeszcze raz zapoznawał się ze stanem ciężko chorych i w razie konieczności wdrażał opisaną wyżej procedurę postępowania. Niezależnie od tych wizyt, określonych w oficjalnym wykazie obowiązków, mógł dokonywać nadzwyczajnych obchodów, by zorientować się, czy nie zaistniały jakieś nowe sytuacje, wymagające szybkiej interwencji. Jak stwierdzono, wielu chorych - biedaczyn (poverelli), przez zakorzenione zło i nieznajomość rzeczy Bożych mogło nie osiągnąć wiecznej szczęśliwości, dlatego cononico direttore, kierując szczególnym miłosierdziem i ojcowską, duszpasterską troską o życie wieczne chorych, powinien być gotów w każdej chwili oferować im pomocną dłoń ${ }^{72}$.

Konkludując,odpowiedzialnośćdyrektorazachorychbyłanieograniczonaiwielostronna. Jego zadaniem było zapewnienie kompleksowej posługi duszpasterskiej i sakramentalnej wszystkim pensjonariuszom, bez względu na stan zdrowotny, oraz koordynowanie służby wobec chorych przez liczną i różnorodną grupe duchownych. W kolejności dyrektor pilnował spowiedzi i komunii nowo przyjętych, ponownej spowiedzi ciężko chorych, udzielania wiatyku i ostatniego namaszczenia, asystencji przy umierających oraz pogłębiania i nauczania tym, którzy tego potrzebowali doktryny chrześcijańskiej ${ }^{73}$.

Ta sama instrukcja z 1759 r., autoryzowana przez Piusa VI (1775-1799), a przekazana do przestrzegania komandorowi szpitala Vincentiemu Mareri na początku lat 90. XVIII wieku, określała nadzorcę duchownych służących w infirmerii szpitalnej terminem padre presidente, zamiast używanego wcześniej tytułu canonico ditrettore, dzierżonego wcześniej przez kanonika Sw. Ducha. Było to tożsame stanowisko, z tym że ok. trzydzieści lat później piastował go kapucyn, który miał do dyspozycji w szpitalu, jako swych podwładnych, grupę 13 (razem z nim) osób z tego samego co on sam zakonu. Jak stwierdzono, ich liczba nie mogła być na przyszłość niższa. W kolejności, według hierarchii, byli to następujący kapłani kapucyńscy: prezydent (przewodniczący), dwóch spowiedników, zakrystian, ośmiu polecających duszę oraz jeden świecki (laico) do ich obsługi, zapewne brat konwers. Całą więc ekipę duszpasterzujących kapelanów stanowili wtedy przybyli z zewnątrz członkowie jednego zakonu. Jak stwierdzono, tworzyli oni swego rodzaju konwikt, w którym zresztą faktycznie zamieszkiwali. O ile prezydent sprawował całkowitą kontrolę na podlegającymi mu współbraćmi, to on sam podlegał dwóm kanonikom - przełożonemu i jego zastępcy, nadzorującym całą infirmeryczną część szpitala. W wolnych chwilach zobowiązany był im pomagać i respektować wydane zalecenia. Miał prawo wychodzić ze szpitala na krótko, co najwyżej dwa razy w tygodniu, najlepiej w porze popołudniowej lub wieczorem. Rezydując przy głównym wejściu do szpitala, nie mógł konwersować

\footnotetext{
${ }^{72}$ Tamże.

${ }^{73}$ Tamże.
} 
z obcymi osobami, za to cały czas wolny poświęcać na kontrolowanie swych współbraci, doglądanie chorych i prowadzenie ewidencji związanej z przyjmowaniem przez chorych wszelkich sakramentów ${ }^{74}$.

Dotychczasowe rozważania, a zwłaszcza przytoczony wyżej regulamin, dowiodły, że dla władz i zwierzchników szpitala priorytetem była troska o wyleczenie duszy poprzez praktyki sakramentalne. Ze źródeł można wysnuć wniosek, że w podejściu do chorego i zaleceniu jednoczesnego leczenia ciała i duszy, w realnym działaniu trudno doszukać tej równowagi i parytetu. W konfrontacji dwóch sfer i wysiłków kuracyjnych terapia duchowa dominowała nad lekarsko-medyczną, a w ogólnej perspektywie przyszłych losów pacjentów przyjętych do szpitala, mniejszą stratą wydawała się „śmierć ciała" niż „śmierć duszy”. Takie postępowanie, swego rodzaju filozofia zbawienia, stosowana wobec chorych nie może dziwić w najbardziej religijnym i chrześcijańskim szpitalu, kierowanym przez najwyższe instancje Kościoła, papieży i Stolicę Apostolską, których fundamentalną, w zasadzie jedyną misją było uchronienie wiernych od piekła i doprowadzenie do zbawienia wiecznego. Zwłaszcza że dotyczyło to osób, które w ogromnej liczbie kończyły tam życie.

\section{REFERENCES / BIBLIOGRAFIA}

\section{Źródła}

Archivio di Stato di Roma (Archivio dell'Archiospedale di S. Spirito)

nr 1409, Decreti di Visita dell'Eminentissimo Cardinal Acciaioli 15 Giugno 1679, w: Notificazione sopra varie disposizioni riguardanti il retto regime, governo, ed administratione dell'Apostolico Archiospedale di Santo Spirito, in Roma MDCCCXV, s. 63-63. nr 1409, Decreto per li sacerdoti dell'Archiospedale. D. Sampieri Commendatore 1781, nr. 3092, Disordini, che sono nel Venerabile Arcispedale di S. Spirito, w: "Buste Misceanae", Assistenza agli infermi spirituali e corporale - Confessori e Raccomandatori dell'anima.

nr 1409, Facoltà di dare le Benedizione in „,Articulo Mortis” agl'Infermi. 1744.

$\mathrm{nr}$ 61, Giornale. Memorie delle cose piu Notabili accadute circa gli Affari del ven. Archiospedale di S. Spirito da 28 Luglio 1758, sino a 28 Dicembre 1759.

$\mathrm{nr} 1409$, Istruzione formata gia d'ordine della S.M. di papa Innocenzo XI rinnovata dalla

Santita di Nostro Signore Papa Clemente XII.

nr 3092, Istruzione per il Direttore delle Cose Spirituali del Venerabile Archiospedale, w:

"Buste Misceanae", Assistenza agli infermi spirituali e corporale - Confessori e Raccomandatori dell'anima.

nr 1049, Licenza di udire le confessioni In lingua francese 1664.

nr 1409, Atti della Visitas dell'Eminentissimo Signor Cardinal Petrucci de 23 agosto 1696.

nr 3092, Memorie sopra la dimissione de Padri Capuccini del servigio dell'Archiospedale.

${ }^{74}$ ASR, nr. 1296, Regolamento da osservarsi dal Padre presidente e Cappelani cosi dispostoe consegnato all'Archivio di questa Pia Casa dal Monsignor Vincenti. 
nr 152, Metodo da tenersi da'Reverendi Sacerdoti Confessori, e raccomandatori di Anime nell'Archiospedale di S. Spirito di Roma nell'amministrare agli Infermi il Santo sagramento dell'Estrema Unzione.

$\mathrm{nr}$ 3092, Notificazione sopra di metodo di tenersi da sacerdoti confessori, e raccomendatori d'Anime per insinuarsico'moribondi dell'Apostolico Archiospedale di S. Spirito in Sassia. In Roma XDCCCXV.

$\mathrm{nr}$ 3, Ordini da osservarsi nel'Hospidale dell'Archiospidale di S. Spiritro in Saxia per decreto dell'Signore Visitatori Apostolici.

nr 27, Ospedale di Santo Spirito. 1658. Rubricella delli Salariati di S. Spirito. 1658, w: Rubricella delli Salariati e ristretto di diverse tenute.

nr 1296, Regolamento da osservarsi dal Padre presidentya e Cappelani cosi dispostoe consegnato all'Archivio di questa Pia Casa dall'Monsignor Vincenti.

$\mathrm{nr}$ 1409, Regolamento de quartieri per li raccomandatori delle anime. Giseppe Maria Castelli 1659.

nr 1409, Regole da osservarsi nell'Arcispedale di San Spirito in Sassia. In Roma Per Michele Cortellini. 1654.

nr 1409, nr 1305, Relazione delle Cose dell'Archiospedale di S. Spirito nell'anno 1759 del ...Cardinal Castelli Pro Commendatore Castelli l'anno 1759, s. 229, w: Notificazione sopra varie providenze riguardanti il regolamento e buon'ordine del Conservatorio di S. Spirito. In Roma MDCCCXVI.

nr 1301, Relazione fatta da Ferrini alla S.S. di tutto quello che si è fatto nello Spedale di S. Spirito, e del transporto dei Rognosi nello Spedale di S. Gallicano con utile.

$\mathrm{nr} 7$, Ristretto del contenuto di dversi chorografii, e decreti, che si conservano nell'Archivio di San Spirito, Memorie d'alcune bolle, brevi, rescritti, prerogative concernenti d'Archiospedale di S. Spirito ed Annessi 1748.

nr 902, Visita Apostolica deputata della Santità di N.S. Papa Clemente XII nel Sagro, et Apostolico Archiospedale, Casa, e Banco di S. Spirito in Sassia di Roma, principiata dall'... Signor Cardinal D. Leandro Porzia Visitatore Apostolico, il di 22 settembre 1737.

Biblioteca Apostolica Vaticana

Barberino Latino 10683, cap. II. Relatione del modo, che si tiene da religiosi di Santo Spirito in Sassia di Roma nel governo dell'Archiospedale Apostolico di Santo Spirito, et dell'ordine, che si osserva nella cura degli infermi, et esposti, scritta da fra Domenico Borgarucci religioso, et secretario del medessimo Ordine, s. 2-29v.

\section{Opracowania}

Gregoire Réginald, „Servizio dell'anima quando del corpo” nell'ospedale romano di Santo Spirito, „Ricerche per la Storia Religiosa di Roma”, 3 (1979) s. 221-254.

Jougan Alojzy, Słownik kościelny łacińsko - polski, Warszawa 1992.

Surdacki Marian, Dzieci porzucone w Rzymie i okolicach w XVIII wieku, ,Roczniki Nauk Społecznych", 22 (1994) z. 2, s. 84-108.

Surdacki Marian, Il brefotrofio dell'Ospedale di Santo Spirito in Roma nel XVIII secolo, Conferenze 115, Varsavia-Roma 2002.

Surdacki Marian, La vita religiosa nel „Conservatorio” dell'ospedale di Santo Spirito in Roma, nei secoli XVII-XVIII, „Ricerche di storia sociale e religiosa”, 27 (1998) nr 54, s. 149-165.

Surdacki Marian, Infirmeria Świętego Ducha w Rzymie w XVII-XVIII wieku. Perspektywy badawcze, „Archiwa Biblioteki i Muzea Kościelne”, 110 (2018) s. 381-394. 


\title{
RELIGIOUS AND SACRAMENTAL LIFE IN THE INFIRMARY OF THE HOSPITAL OF THE HOLY SPIRIT IN ROME IN THE 17TH-18TH CENTURIES
}

\begin{abstract}
The hospital Order of the Holy Spirit, founded at the end of the 12th century by Guidon of Montpellier, played a major role in the development of hospitals. He ran the largest in Europe Holy Spirit Hospital in Rome, founded in 1198 by Pope Innocent III, which became a model for other hospitals in the Christian world. It performed two functions: an asylum for foundlings (brefotrophium) and a hospital-infirmary for the sick. Both of these institutions, were unmatched in Europe in terms of the number of charges (foundlings and the sick). In the last quarter of the 18th century, it could accommodate 2,000 people, most of them sick.

In the old days, hospitals that were under church management were places where the religious life of those under their care was taken special care of. The physical healing of the sick and the salvation of their soul was cherished with the same care. This was also the case at the Holy Spirit Hospital in Rome.

Practical care for the spiritual life of the sick and their completion of the sacraments belonged to the confessors on duty, as well as to the priests who recommended the souls of the dying to God (raccommandatori dell'anime). In the 17 th century, they were all monks of the Holy Spirit. In later times, especially in the 18th century, these functions were often performed by priests from outside the hospital, mainly Capuchins. The number of the clergymen changed depending on the needs, usually increasing in summer, along with the constant increase in the incidence rate and thus the increase in mortality in hospitals.

The main duty of confessors and those recommending souls to God was administering the sacrament of penance for hospital boarders, especially newcomers, and in a life-threatening situation, giving them viaticum and the last anointing at each call on duty. In their spare time, they were to deepen the foundations of the Christian faith of the sick. Holy Communion was always given to the sick as a consequence of confession. Efforts were made that none of the sick would die without the sacraments and that a priest would always be present with the dying, recommending the soul of the dying person to God.
\end{abstract}

Keywords: Holy Spirit Hospital; religious life; sacraments; confessors; Rome; the sick 